\title{
Microbiological and physicochemical studies of spent lubricating oil contaminated soil amended with wood ash
}

\author{
Stephen, $\mathrm{E}^{1^{*}}$., Okwute, L. O. ${ }^{2}$, Peter, J. 0. ${ }^{1}$ and Ekeyi, D. ${ }^{1}$ \\ 1Department of Microbiology, Kogi State University, P.M.B. 1008, Anyigba- Kogi State, Nigeria. \\ ${ }^{2}$ Department of Microbiology, University of Abuja, P.M.B. 117, Gwagwalada- Abuja, Nigeria. \\ ${ }^{*}$ Corresponding author. Email: stephen.e@ksu.edu.ng. Tel: +234-8036347036.
}

Copyright @ 2016 Stephen et al. This article remains permanently open access under the terms of the Creative Commons Attribution License 4.0, which permits unrestricted use, distribution, and reproduction in any medium, provided the original work is properly cited.

Received 11th May, 2016; Accepted 28th June, 2016

\begin{abstract}
Microbiological and physicochemical studies of spent lubricating oil contaminated soil amended with wood ash $(10 \%$ amendment level) were carried out for a period of 56 days. The aim of this study was to evaluate the effect of wood ash in conditioning spent lubricating oil contaminated soil. Serial dilution and pour plate methods were used in enumerating microbial growth. The $\mathrm{pH}$, nitrate, moisture, phosphorus, organic matter content were also determined. The heterotrophic bacteria count ranged from $1.0 \times 10^{4}$ to $2.1 \times 10^{4} \mathrm{cfu} / \mathrm{g}$ for the oil free soil (OFS), $1.3 \times 10^{4}$ to $2.7 \times 10^{4} \mathrm{cfu} / \mathrm{g}$ for the polluted control soil (PCS) and $2.1 \times 10^{4}$ to $2.3 \times 10^{4} \mathrm{cfu} / \mathrm{g}$ for the amended soil (AS) while the fungal count ranged from $4.0 \times 10^{3}$ to $4.7 \times 10^{4} \mathrm{cfu} / \mathrm{g}$ for OFS, $4.0 \times 10^{3}$ to $8.2 \times 10^{4} \mathrm{cfu} / \mathrm{g}$ for PCS and $4.0 \times 10^{3}$ to $10.8 \times 10^{4} \mathrm{cfu} / \mathrm{g}$ for AS. Higher microbial counts were found on the PCS and AS compared to the OFS. There were no significant differences at $5 \%$ probability level between the treatments. The organisms isolated were species of Bacillus, Staphylococcus, Micrococcus, Aspergillus, Mucor, Penicillium and Saccharomyces. There were no significant differences ( $p>0.05)$ in the moisture content, nitrate, organic matter content and electrical conductivity. However, there were significant differences in the $\mathrm{pH}$, organic carbon and phosphorus contents of the soil samples at $5 \%$ probability level. The results obtained in this study demonstrate the potential of wood ash to considerably increase the organic carbon, phosphorus and $\mathrm{pH}$ of the soil to slightly alkaline condition which favours the biodegradation of the spent lubricating oil contaminated soil.
\end{abstract}

Key words: Ash, contaminated soil, microbial count, physicochemical studies, spent lubricating oil.

\section{INTRODUCTION}

Onuoha et al. (2011) reported that indiscriminate disposal and contamination of soil by used lubricating oil is prevalent in developing countries where there are no effective regulatory policies on the environment. According to the authors, oil spills from industries, filling stations and activities of automechanic workshops, all combine to contribute to soil contamination by hydrocarbons (Ndubuisi-Nnaji et al., 2015).

Pollution by spent lubricating oil has not drawn much public attention especially in developing countries like Nigeria (Stephen et al., 2013). Boonchan and Stanley (2000) are of the opinion that used motor oil contains metals and heavy polycyclic aromatic hydrocarbons (PAHs) that could contribute to chronic hazards including mutagenicity and carcinogenicity.
The problems of pollution have led to the exploration of many remedial approaches to effect the restoration of the polluted soils. One of such strategies is biodegradation. This is favored as a good option for the remediation of polluted sites mainly because it is environmentally friendly and simple (ljah et al., 2000).

The process of biodegradation relies on microbial enzymatic activities to transform or degrade the contaminants in the environment (Philips and Atlas, 2005). This method has been investigated by several researchers to remediate petroleum polluted soil using various nutrient sources such as inorganic fertilizer, urea, compost manure and biosolids (Cho et al., 1997, Namkoong et al., 2002, Okwute and ljah, 2014).

According to Wang et al. (2000), the problem of environ- 
mental pollution has assumed an unprecedented proportion in many areas of the world. Human and ecosystem are exposed to chemicals emanating from spent hydrocarbons through direct contact with soil or via inhalation of soil contaminants which have vaporized. Also, most heavy metals such as vanadium, copper, aluminum, nickel and iron, which were below detection in unused lubricating oil, have been reported by Stephen et al. (2013) to give high values in used oil. These heavy metals may be retained in soils in the form of oxides, hydroxides, carbonates, exchangeable cations, and/or bound to organic matter in the soil (Yong et al., 1992).

One common scenario of lubricating oil contamination is the indiscriminate discharge of spent lubricating oil (SLO) in the soil by mechanics during the changing of spent engine oil in automobiles. This has lead to blackish and hardened surface of the soil making it unfit for agricultural activities. In Nigeria, oil pollution problem has been prevalent since the commencement of oil exploration and establishment of the petroleum industry (Okoh et al., 2001). Different methods have been used in the biodegradation of oil polluted soils; some of these include the use of oil degrading microorganisms (Okwute et al., 2015, Ndubuisi-Nnaji et al., 2015), chicken droppings (Okwute and ljah, 2014), melon shells, sawdust, rice husk, meshed groundnut husk (Stephen et al., 2013; Stephen and Temola, 2014).

Due to the unproductive nature of spent lubricating oil polluted soil, there is a need to reclaim such soil using a cheap, safe and readily available product. Wood ash is cheaper than inorganic fertilizer and readily available in Nigeria because a lot of people still use fire wood to cook. Wood ash is the residue powder left after the combustion of wood, such as burning wood in a home fireplace or an industrial power plant. It is used traditionally by gardeners as a good source of potassium for domestic gardens or any garden. Misra et al. (1993) reported that between 0.43 and 1.82 percent of the mass of burnt wood (dry basis) results in ash. Etiegni and Campbell (1991) are of the opinion that the condition of combustion of wood such as higher temperature affects the composition and amount of the residual ash.

Wood ash is commonly disposed off in landfills, but with rising disposal costs, ecologically friendly alternatives are becoming more popular (Demeyer et al., 2001). For a long time, wood ash has been used in agricultural soil applications as it recycles nutrients back to the soil. Wood ash has some value as a fertilizer, but does not contain nitrogen. Because of the presence of calcium carbonate it acts as a liming agent in acidic soil by increasing its $\mathrm{pH}$ (Misra et al., 1993). The significance of this study lies in the use of cheap and readily available wood ash to enhance the degradation of spent lubricating oil contaminated soil by increasing the $\mathrm{pH}$, phosphorus and organic matter content of the affected soil such as abandoned mechanic workshop so as to put it to agricultural uses.

\section{MATERIAL AND METHODS}

\section{Experimental Design}

A portion of land measuring 1 by 3 meter square was tilled and separated into 3 equal plots measuring $1 \mathrm{~m}^{2}$ each. They were labelled $A, B$, and $C$ respectively. Plots $A$ and $B$ were polluted with 10 liters of spent lubricating oil each while plot $C$ was free of oil and served as control. After 7 days, $1 \mathrm{~kg}$ of wood ash was applied to plot A and thoroughly mixed with the soil. This served as $10 \%$ amendment level. The spent lubricating oil was collected from automobile workshop close to Kogi State University, Anyigba, Nigeria.

\section{Sampling}

Samples were collected as described by Stephen and Temola (2014). Composite soil samples were randomly collected from each plot and were collected from at least three (3) different locations in each plot at a depth of 5 to10 $\mathrm{cm}$ and mixed together. The sampling commenced at day 0 and then two (2) weeks after treatment. Subsequent soil samples were collected bi-weekly to determine the microbiological and physicochemical parameters of the soil for duration of eight weeks (56 days).

\section{Microbiological and physicochemical analysis}

The soil samples from the three plots were analyzed microbiologically as described by Public Health England (2014). The $\mathrm{pH}$ was determined as described by lbitoye (2006). Nitrate was determined by the micro Kjedahl method (AOAC, 2005). The phosphorus and moisture content were determined using the Soil Survey laboratory (1996) method. The ignition method of Akinsanmi (1975) was used to determine the organic matter content while the dry weight method of Tropical Development Institute, TDI (1984) was used to determine the moisture content. Descriptive statistics and analysis of variance (ANOVA) was performed using procedure of SPSS version 16 (2007). Experimental precision achieved was reported at $\mathrm{p} \leq 0.05$ level.

\section{RESULTS}

The total bacterial count obtained from oil free soil (control), polluted control and amended soil is shown in Figure 1. The bacterial count ranged from $1.0 \times 10^{4}$ to $2.1 \times 10^{4} \mathrm{cfu} / \mathrm{g}$ for oil free soil (OFS), $1.3 \times 10^{4}$ to $2.7 \times 10^{4}$ $\mathrm{cfu} / \mathrm{g}$ in polluted control soil (PCS) and $2.1 \times 10^{4}$ to $2.3 \times 10^{4} \mathrm{cfu} / \mathrm{g}$ in amended soil (AS). The highest bacterial population was observed in the PCS at day 28 . There was a decline in the bacterial count in all treatments after 


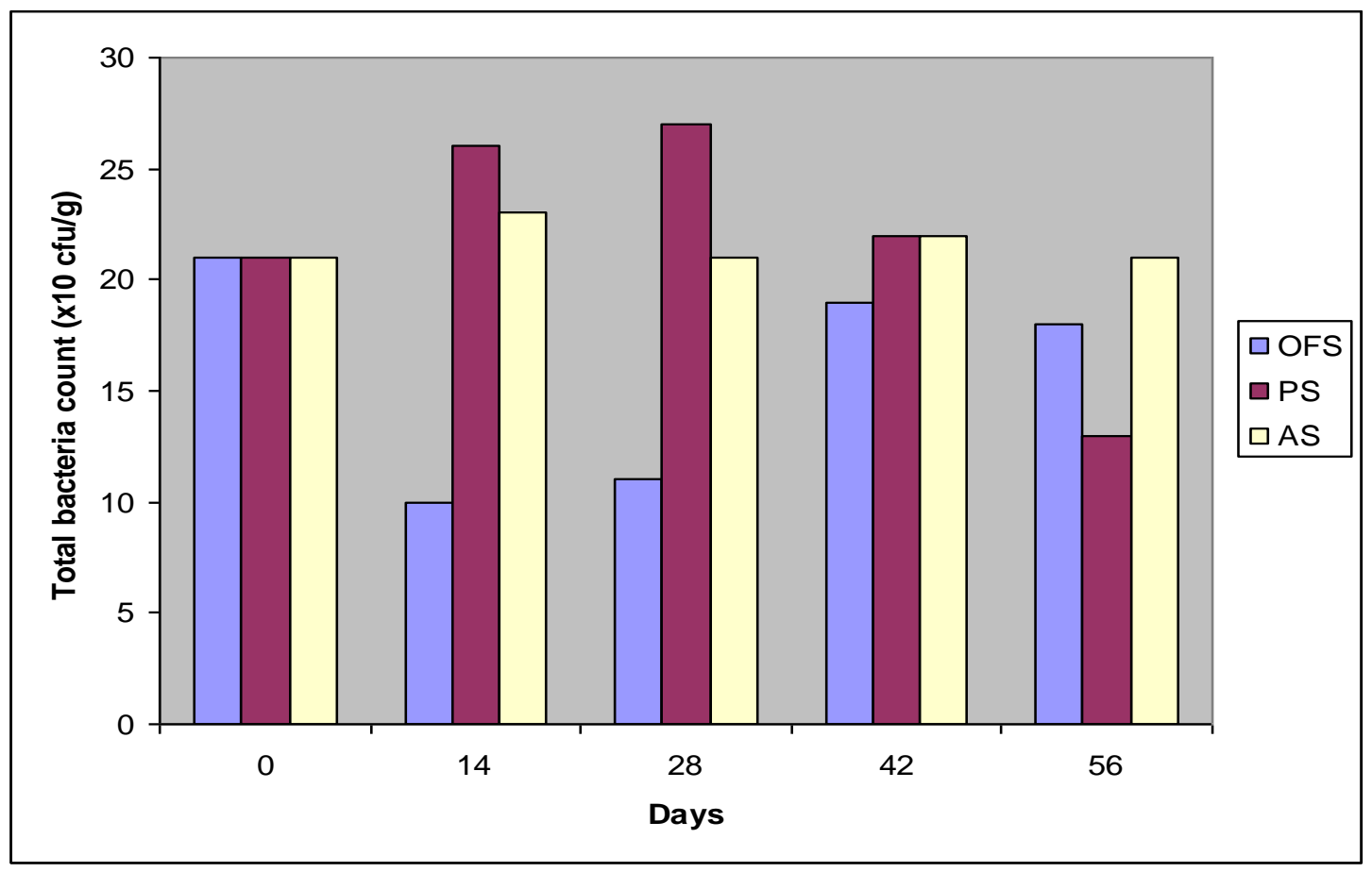

Figure 1. Total bacterial count in spent lubricating oil contaminated soil undergoing biodegradation. OFS: Unpolluted soil, PCS: Polluted control soil, AS: Amended soil.

day 42. There were no significant differences $(p>0.05)$ between the treatments. The bacteria isolated and identified were Bacillus sp, Micrococcus sp, Staphylococcus sp and Proteus sp. The total fungal count obtained from the soil samples is shown in Figure 2. The fungal count ranged from $4.0 \times 10^{3}$ to $4.7 \times 10^{4} \mathrm{cfu} / \mathrm{g}$ in the oil free soil (OFS), $4.0 \times 10^{3}$ to $8.2 \times 10^{4} \mathrm{cfu} / \mathrm{g}$ in polluted control soil (PCS) and $4.0 \times 10^{3}$ to $10.8 \times 10^{4} \mathrm{cfu} / \mathrm{g}$ in amended soil (AS). The highest count was observed in AS at day 56. There was an increase in fungal count in all the treatments after 28 days. However, there was no significant difference $(p>0.05)$ between the treatments. The fungi isolated and identified in this study were Saccharomyces sp, Aspergillus niger, Mucor sp, Penicillium sp.

Table 1 shows the result of the physicochemical parameters examined during the study. The $\mathrm{pH}$ ranged from $5.39 \pm 0.30$ to $7.62 \pm 0.68$. Weakly acidic $\mathrm{pH}$ was observed in both oil free soil and polluted control soil while amended soil was weakly alkaline. There were significant differences $(\mathrm{p} \leq 0.05)$ in the $\mathrm{pH}$ between the treatments.

The moisture content was low in the soil samples. The highest moisture content was observed in OFS while the least moisture content was observed in the amended soil. There was no significant difference in the moisture content between the OFS, PCS and AS at $5 \%$ probability level.

The nitrogen content of the oil free soil was low compared to the polluted control soil and the soil amended with ash. The nitrogen content ranged from $0.19 \pm 0.24$ to $0.49 \pm 0.10 \%$. There was no significant difference in the nitrogen content between the OFS, PCS and $A S$ at $5 \%$ probability level.

The highest available phosphorus content was observed in the Amended soil (AS) followed by polluted control soil (PCS). The phosphorus concentration ranged from $8.61 \pm 1.67$ to $15.05 \pm 1.21 \%$. There was no significant difference in the phosphorus content in all the treatments at $5 \%$ probability level.

A progressive increase in the organic carbon from OFS, PCS to AS was observed in this study. The organic carbon ranged from $0.88 \pm 0.19$ to $1.23 \pm 0.45 \%$. There was no significant difference $(p>0.05)$ in the organic carbon between the treatments.

A similar trend in the organic carbon was observed in the organic matter content. The highest value of the organic matter content was observed in amended soil (AS) while the least value was observed in oil free soil (OFS). The organic matter content ranged from $1.51 \pm 0.33$ to $3.85 \pm 0.79 \%$. There was no significant difference in the organic matter content between the treatments at $5 \%$ probability level. The electrical conductivity was low throughout the period of study regardless of treatment. It ranged from $0.25 \pm 0.04$ to $0.43 \pm 0.06 \mathrm{Ms} / \mathrm{cm}$. There was no significant difference in the organic matter content between the treatments at $5 \%$ probability level. 


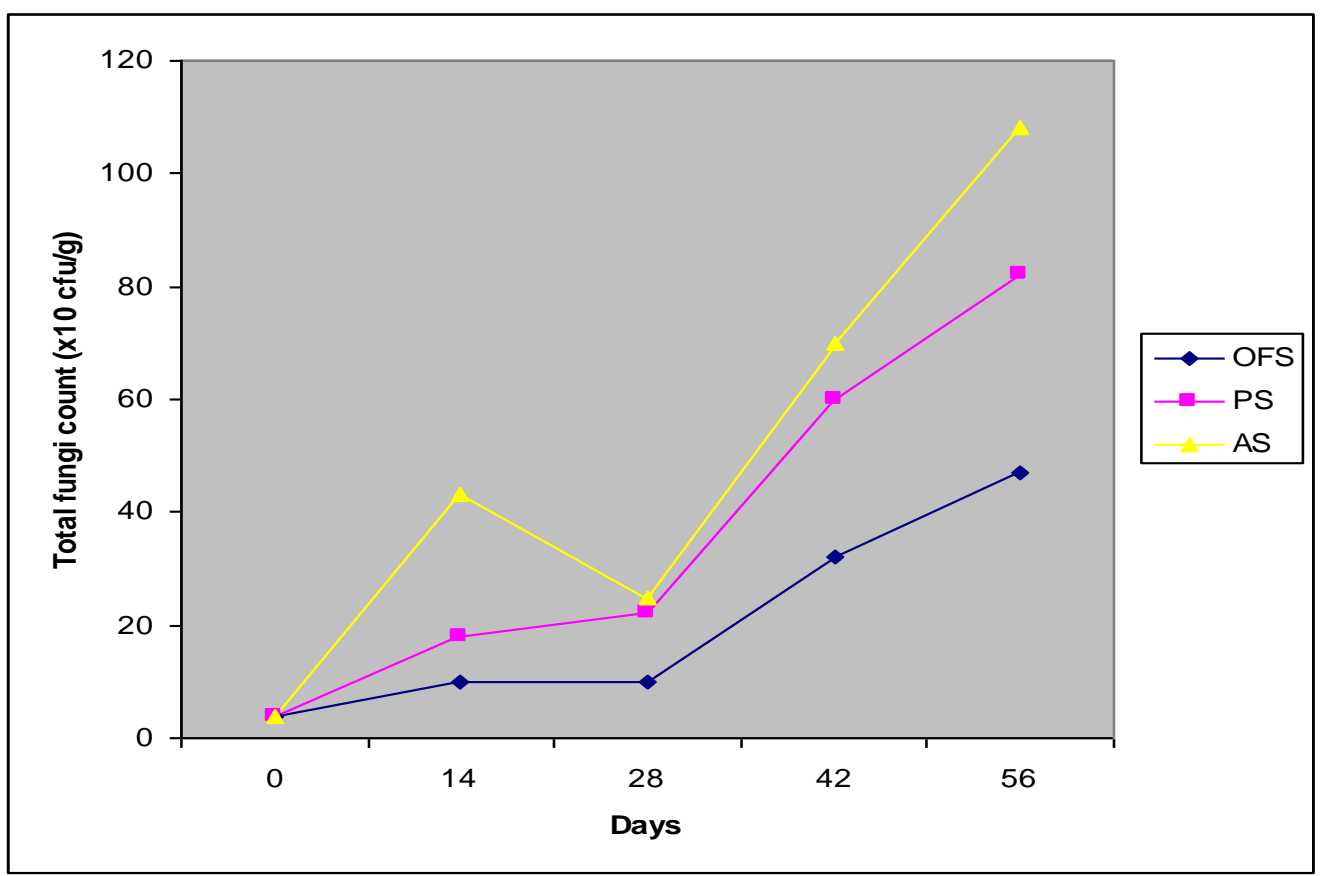

Figure 2. Total fungal count in spent lubricating oil contaminated soil undergoing biodegradation. OFS, Unpolluted soil, PCS, Polluted control soil, AS, Amended soil.

Table 1. Physicochemical qualities of mechanic workshop polluted soil (M+SE)

\begin{tabular}{lccc}
\hline Parameter & OFS & PCS & AS \\
\hline $\mathrm{pH}$ & $5.39 \pm 0.30^{\mathrm{b}}$ & $5.99 \pm 0.27^{\mathrm{a}, \mathrm{b}}$ & $7.62 \pm 0.68^{\mathrm{a}}$ \\
Moisture (\%) & $3.20 \pm 0.71^{\mathrm{a}}$ & $0.42 \pm 0.09^{\mathrm{a}}$ & $0.25 \pm 0.04^{\mathrm{a}}$ \\
Nitrogen (\%) & $0.19 \pm 0.24^{\mathrm{a}}$ & $0.43 \pm 0.09^{\mathrm{a}}$ & $0.49 \pm 0.10^{\mathrm{a}}$ \\
Phosphorus (\%) & $8.61 \pm 1.67^{\mathrm{a}}$ & $10.67 \pm 2.51^{\mathrm{a}}$ & $15.05 \pm 1.21^{\mathrm{a}, \mathrm{b}}$ \\
Organic carbon (\%) & $0.88 \pm 0.19^{\mathrm{a}}$ & $1.97 \pm 0.42^{\mathrm{a}}$ & $2.23 \pm 0.45^{\mathrm{a}, \mathrm{b}}$ \\
Organic matter (\%) & $1.51 \pm 0.33^{\mathrm{a}}$ & $3.49 \pm 0.78^{\mathrm{a}}$ & $3.85 \pm 0.79^{\mathrm{a}}$ \\
EC(Ms/cm) & $0.43 \pm 0.06^{\mathrm{a}}$ & $0.42 \pm 0.09^{\mathrm{a}}$ & $0.25 \pm 0.04^{\mathrm{a}}$ \\
\hline
\end{tabular}

a,b,c, Mean with different alphabets along the same row are significantly $(p<0.05)$ different. Results are presented as the mean and standard error of the mean, where $n=5$. OFS, Unpolluted soil, PCS, Polluted control soil, AS, Amended soil, EC, Electrical conductivity.

\section{DISCUSSION}

The result from the microbial analysis in this study revealed that the total bacterial count was stable in the amended soil (AS) compared to the polluted control soil (PCS) and oil free soil (OFS). This may be due to the continued availability of organic matter in the AS while the organic matter content in the PCS reduced with time (Stephen and Temola, 2014).

The fungal count was higher in the amended soil compared to the polluted control and oil free soil. This may be due to the weakly alkaline nature of the amended soil (AS) as a result of the ash. This result is in agreement with earlier works by Stephen et al. (2013) who observed higher fungi count on diesel polluted soil amended with cowpea chaff compared to polluted control soil and oil free soil with time.

The organisms isolated were Bacillus sp, Staphylococcus $\mathrm{sp}$, Micrococcus sp, Aspergillus niger, Mucor sp, Penicillium and Saccharomyces sp. These organisms have been isolated by many researchers working on oil polluted soil (ljah, 1998; Van-hamme et al., 2003; Bento et al., 2005; Onuoha et al., 2011; Okwute and ljah, 2014).

The $\mathrm{pH}$ was found to be higher in the amended soil compared to the polluted control soil and the oil free soil. This could be due to the addition of wood ash which was reported by Mijangos et al. (2004) to be a source of fertilizer and soil conditioner suitable for biodegradation 
activities. It was observed that there was a gradual change in $\mathrm{pH}$ with time from weakly acidic to slightly alkaline $\mathrm{pH}$ possibly in response to the application of the wood ash. There were studies which showed that degradation of oil increased with increasing $\mathrm{pH}$, with optimum degradation occurring under slightly alkaline conditions (Foght and Westlake, 1997). The pH values obtained from this study corroborate the work of Foght and Westlake (1997) and ljah and Ndana (2000) who observed similar findings.

The moisture content was low in all treatments. However, this may be as a result of the harmattan since the study was carried out in the dry season (Dec 2014 to Feb 2015). This is in contrast with the works of Stephen and Egene (2012) who observed high moisture content in spent lubricating oil polluted soil during the rainy season. However, higher moisture content was observed in the amended soil and the polluted control soil. This may be due to low permeability and low infiltration of water in the spent lubricating oil polluted soil undergoing biodegradation (Stephen et al., 2013).

The nitrogen content was low in all treatments. However, higher values were observed in the polluted soil and amended soil. This may be due to the presence of nitrogenous compounds present in the spent lubricating oil used in the pollution of both the polluted soil and soil amended with wood ash compared to the oil free soil (Stephen and Egene, 2012).

The phosphorus content was observed to be higher in the amended soil than the polluted soil and oil free soil. This may be as a result of the addition of wood ash which contains high concentrations of potassium and phosphorus (Hume, 2006). Also, the phosphorus content was found to be higher in polluted soil than the oil free soil. This may be due to the addition of spent lubricating oil since hydrocarbon is known to contain phosphorus compounds (Stephen and Egene, 2012).

The organic carbon and organic matter content were low in all the soil treatments. This may be due to microbial utilization of the organic matter and carbon for their growth and metabolism. Carbon also serves as source of nutrients and is required for biodegradation (Stephen and Temola, 2014). However, the organic carbon and organic matter content were higher in the amended soil than oil free soil and the polluted control soil. This may be due to the addition of the wood ash.

The electrical conductivity (EC) was found to be lower in the amended soil than the polluted soil and oil free soil. This may be due to the addition of wood ash that was used for amendment which caused an increase in $\mathrm{pH}$ of the soil toward alkalinity. This corroborates with the findings of other researchers who found EC to increase with acidity of a soil (Stephen et al., 2013).

\section{Conclusion}

The potential of wood ash in enhancing biodegradation of spent lubricating oil as an alternative to the use of inorganic fertilizers is very promising. The results of this study revealed that biodegradation of petroleum hydrocarbon were significantly enhanced by the addition of the wood ash which increased phosphorus availability, organic carbon and reduced soil acidity level thus serving as an alternative to lime and other commercial fertilizers for soil conditioning.

\section{CONFLICT OF INTEREST}

The authors declare that they have no conflict of interest.

\section{REFERENCES}

Akinsanmi, O. (1975). Certificate Agricultural Science. Longman, Nigeria, Pp.104-112

AOAC International (2005). Official method of analysis of AOAC international. Chemistry and analytical laboratory manual (18 th ed.).

Bento, F. M., Carmago, F. O. A., Okeke, B. C., \& Frankenberger, W. T. (2005). Comparative bioremediation of soil contaminated with diesel oil by natural attenuation, biostimulation and bioaugmentation. Bioresource Technology, 96, $1049-1055$.

Boonchan, M. L., \& Stanley, G. A. (2000). "Degradation and mineralization of high moleculartoweight polycyclic aromatic hydrocarbons by defined fungal-bacterial co-cultures," Applied and Environmental Microbiology, 66(3), 1007-1019.

Cho, B. H., Chino, H., Tsuji, H., Kunito, T., Nagaoka, K., Otsuka, S., Yamashita, K., Matsumoto, S \& Oyaiz, H (1997). Laboratory -scale bioremediation of a contaminated soil of Kuwait with amendment materials. Chemosphere, 35 (7), 1599-1611.

Demeyer, A., Voundi Nkana, J. C., \& Verloo, M. G. (2001). Characteristics of wood ash and influence on soil properties and nutrient uptake: an overview. Bioresource Technology, 77(3), 287-295.

Etiegni, L., \& Campbell, A. G. (1991). Physical and chemical characteristics of wood ash. Bioresource Technology, 37(2), 173.

Foght, J. M., \& Westlake, D. W. S. (1997) Biodegradation of hydrocarbons in freshwater. In: Vandermeulen and Hrudey (Ed), Oil in Freshwater: Chemistry, Biology, Counter measure Technology. Pergamon Press, New York, Pp. 217-230.

Ibitoye, A. A. (2006). Laboratory Manual on Basic Soil Analysis $\left(2^{\text {nd }}\right.$ ed). Foladave Nigeria Limited, Akure, Pp. 30-37.

ljah, U. J. J. (1998). Studies on relative capabilities of bacterial and Yeasts isolates from tropical soils in degrading crude oil. Waste Management, 18, 293-299.

Ijah, U. J. J., Tambaya, K., \& Uwabujo, A. E. (2000). The fate of spilled kerosene in the soil: A case study of kerosene spillage in Maikunkele, Niger state, Nigeria. Journal of Nigerian Association of Teachers of Technology, 3, 275-283.

ljah, U. J. J., \& Ndana, M (2000). Stimulated biodegradation of crude oil in soil amended with periwinkle shells. The Environmentalist, 23, 249-254.

Mijango, I., Garbisu, C., Aristegieta, A., Mendarte, S., \& Albizu, I. (2004). Wood ash as fertilizer and soil acidity corrector: effect on soil quality and crop yield. Basque Institute of Agricultural Research and Development. Pp. 808-810. 
Misra, M. K., Ragland, K. W., \& Baker, A. J. (1993). Wood Ash Composition as a Function of Furnace Temperature. Biomass and Bioenergy 4(2), 103-116.

Namkoong, W., Hwang, E., Park, J., \& Choi, J. (2002). Bioremediation of diesel contaminated soil with composting. Environmental Pollution, 119, 23-31.

Ndubuisi-Nnaji, U. U., John, O. U. M., \& Ofon, U. A. (2015). Population dynamics and distribution of hydrocarbon utilizing bacteria in Automobile workshops within Uyo metropolis, Akwa Ibom State. Journal of Applied Science and Environmental Management, 19(4), 585-589

Onuoha, S. C., Olugbue, V. U., Uraku, J. A., \& Uchendu, D. O. (2011). Biodegradation potentials of hydrocarbon degraders from waste -lubricating oil spilled soils in Ebonyi State, Nigeria. International Journal of Agriculture and Biology, 13, 586-590.

Okoh, I. A., Ajisebutu, S., Babalola, G. O., \& Trejo-Hernandez, M. R. (2001). A study of the potentials of Burkholderia cepacill Strain (RQI) in the biodegradations of heavy crude oil (Maya). International Microbiology. 4, 83-87.

Okwute, L. O. Stephen, E., \& Anyanwu, P. I. (2015). Biodegradation of palm oil mill effluent (POME) and Lipase Activity by Pseudomonas aeruginosa, Bacillus subtilis and Candida albicans. British Microbiology and Research Journal, 9(5), 1-10.

Okwute, L. O., \& ljah, U. J. J. (2014). Changes in Microbial Population of Palm oil mill effluent polluted soil amended with chicken droppings and cow dung. British Biotechnology Journal, 4(3), 279-288.

Philips, J. C., \& Atlas, R. M. (2005). Bioremediation of contaminated soil and aquifers. In: Bioremediation: Applied Microbial solution for real world environmental clean Up, Atlas, R.M., and Jim, C.P (Ed) ASM press, ISBN 1 to55591to239to2, Washington, D.C, Pp.139.

Public Health England (2014). Preparation of samples and dilutions, plating and sub-culture. Microbiology Services. Food, Water and Environmental Microbiology Standard Method FNES26 (F2). Version 1
Soil Survey Laboratory (1996). Soil survey laboratory methods manual. Soil survey investigations report no. 42. Ver. 3.0. USDAtoNRCS, Lincoln, NE.

Stephen, E., \& Egene, U. M. (2012). Microbiology and physicochemical properties of soil polluted with lubricating oil in Anyingba, Kogi State, Nigeria. Nigerian Journal of Technological Research, 7(2), 49-52.

Stephen, E., Job, O. S., \& Abioye, O. P. (2013). Study on Biodegradation of Diesel contaminated Soil Amended with Cowpea Chaff. Journal of Science and Multidisciplinary Research, 2(1),14-18.

Stephen, E., \& Temola, O. T. (2014). Enhanced Biodegradation of Spent Lubricating Oil Contaminated Soil Using Poultry Litter. British Biotechnology Journal, 4(8), 868-876.

Tropical Development Institute (TDI) (1984). Outlined method for the determination of organic matter content.

Van Hamme, J. D., Singh, A., \& Ward, O. P. (2003). Recent advances in petroleum Microbiology. Molecular Biology Review, 67, 503-549.

Wang, J., Jiq, C. R., Wong, C. K., \& Wong, P. K. (2000). Characterization of polycyclic aromatic hydrocarbons created in lubricating oils. Water, Air and Soil Pollution, 120, 381-396.

Yong, R. N., Mohammed, A. M. O., \& Warkentin, B. P. (1992). Principles of contaminant transport in soils. Elsevier Science Publishers, Amsterdam. 258p. 